\title{
Upper Neches River Basin Caddo Ceramic Vessels from Anderson, Cherokee, and Henderson Counties in East Texas
}

Timothy K. Perttula

Heritage Research Center, Stephen F. Austin State University

Follow this and additional works at: https://scholarworks.sfasu.edu/ita

Part of the American Material Culture Commons, Archaeological Anthropology Commons, Environmental Studies Commons, Other American Studies Commons, Other Arts and Humanities Commons, Other History of Art, Architecture, and Archaeology Commons, and the United States History Commons

Tell us how this article helped you.

This Article is brought to you for free and open access by the Center for Regional Heritage Research at SFA ScholarWorks. It has been accepted for inclusion in Index of Texas Archaeology: Open Access Gray Literature from the Lone Star State by an authorized editor of SFA ScholarWorks. For more information, please contact cdsscholarworks@sfasu.edu. 
Upper Neches River Basin Caddo Ceramic Vessels from Anderson, Cherokee, and Henderson Counties in East Texas

\section{Creative Commons License}

(c) (1) (8)

This work is licensed under a Creative Commons Attribution-NonCommercial 4.0 International License 


\title{
Upper Neches River Basin Caddo Ceramic Vessels from Anderson, Cherokee, and Henderson Counties in East Texas
}

\author{
Timothy K. Perttula
}

\section{Introduction}

The National Museum of Natural History, Smithsonian Institution (NMNH) has extensive collections of artifacts from ancestral Caddo sites in the Caddo area. This includes 19 ceramic vessels and one distinctive ceramic pipe from several sites in the upper Neches River basin in East Texas (Figure 1). The majority of these artifacts were originally collected by noted amateur archaeologist R. King Harris of Dallas, Texas, who sold his collection to the NMNH in 1980, while three of the vessels were originally in Bureau of American Ethnology holdings, and likely are from early archaeological investigations by Dr. J. E. Pearce (1920) of The University of Texas at Austin that were funded by the Bureau of American Ethnology (BAE). Pearce (1932:51) began work in this part of the state under the auspices of the BAE, and that work "had led me to suppose that I should find this part of the State rich in archeological material of a high order."

\section{Ceramic Vessels}

\section{Anderson County}

Three of the ceramic vessels came from a site near Frankston, Texas, likely in the Caddo Creek valley, an area of the upper Neches River basin with a notable high density of ancestral Caddo settlements and cemeteries. These three vessels were originally in BAE holdings, and include Late Caddo Frankston phase (ca. A.D. 1400-1680) vessels: two carinated bowls and a bottle with a carinated body. The carinated bowls are Poynor Engraved, var. $O$ (Figure 2; see Perttula 2011:Figure 6-65) and var. unspecified (Figure 3) vessels, and the bottle is also a Poynor Engraved vessel (Figure 4; see also Suhm and Jelks 1962:Figure 63h-j).

The last of the Anderson County vessels is a Patton Engraved, var. Freeman globular carinated bowl from Harris' site A-1 (Figure 5). This is the stylistically earliest of the historic Allen phase (ca. postA.D. 1680) Caddo varieties of Patton Engraved in the upper Neches River basin (Perttula 2011:Figure 6-66c).

\section{Cherokee County}

The 11 ceramic vessels and one ceramic elbow pipe are from an unknown site excavated by Harris in Cherokee County in the upper Neches River basin that he referred to as 392/Ch-1. He excavated at least six ancestral Caddo burials at the site, but the vessels are specified as coming from Burials 2 and 6.

Only one vessel from this Cherokee County site is plain. This is a small bowl with an inverted rim (Figure 6).

There are three bottles in the collection from this Cherokee County site (Figures 7-9). Two have globular bodies and short but direct rims and flat lips, and are decorated either with sets of vertical engraved lines (Figure 7, Poynor Engraved) or horizontal and overlapping brushing marks (Figure 9). One bottle has the classic elongated body and short neck of the Hume Engraved type (see Suhm and 


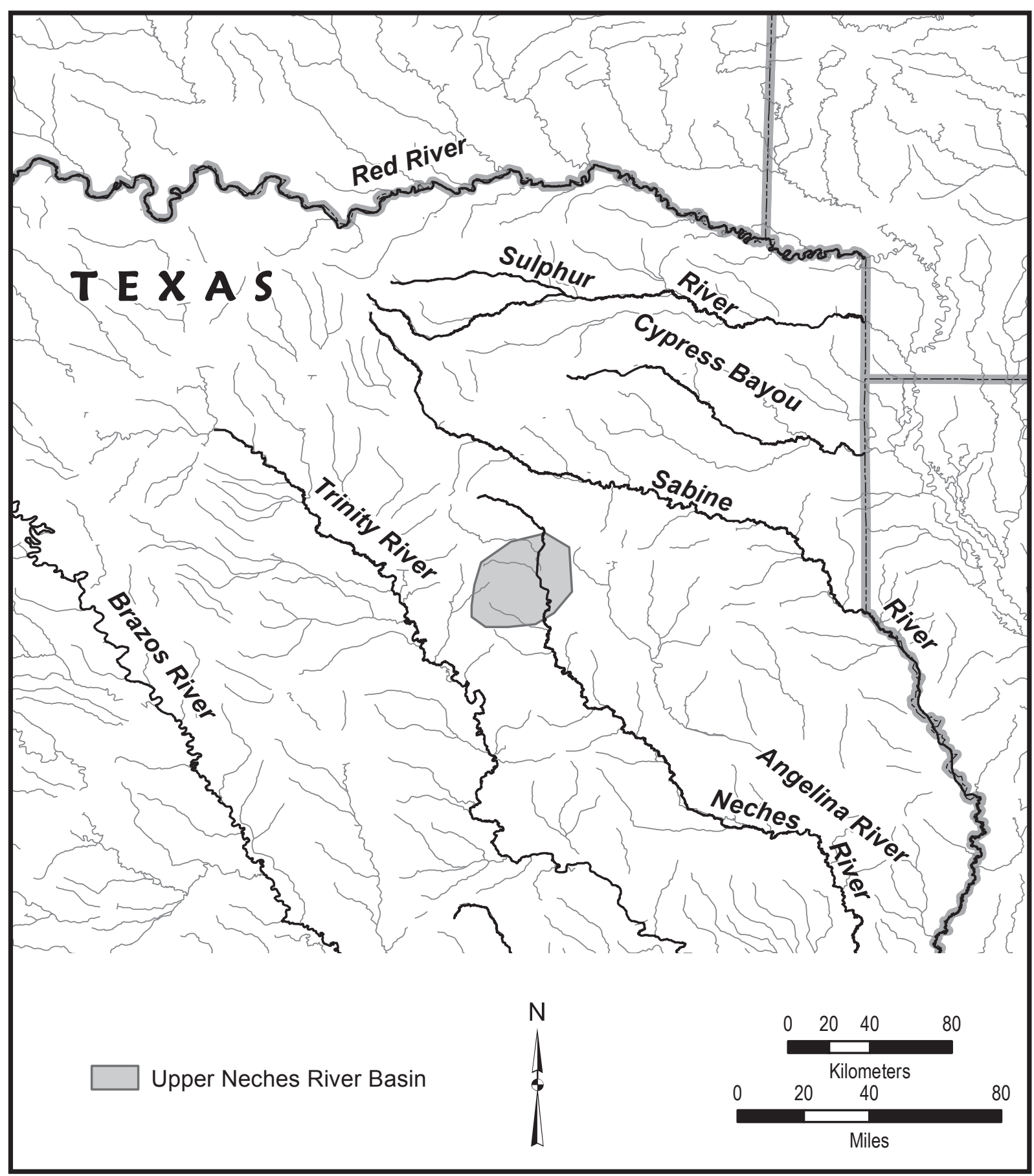

Figure 1. The location of the Upper Neches River Basin in East Texas. 


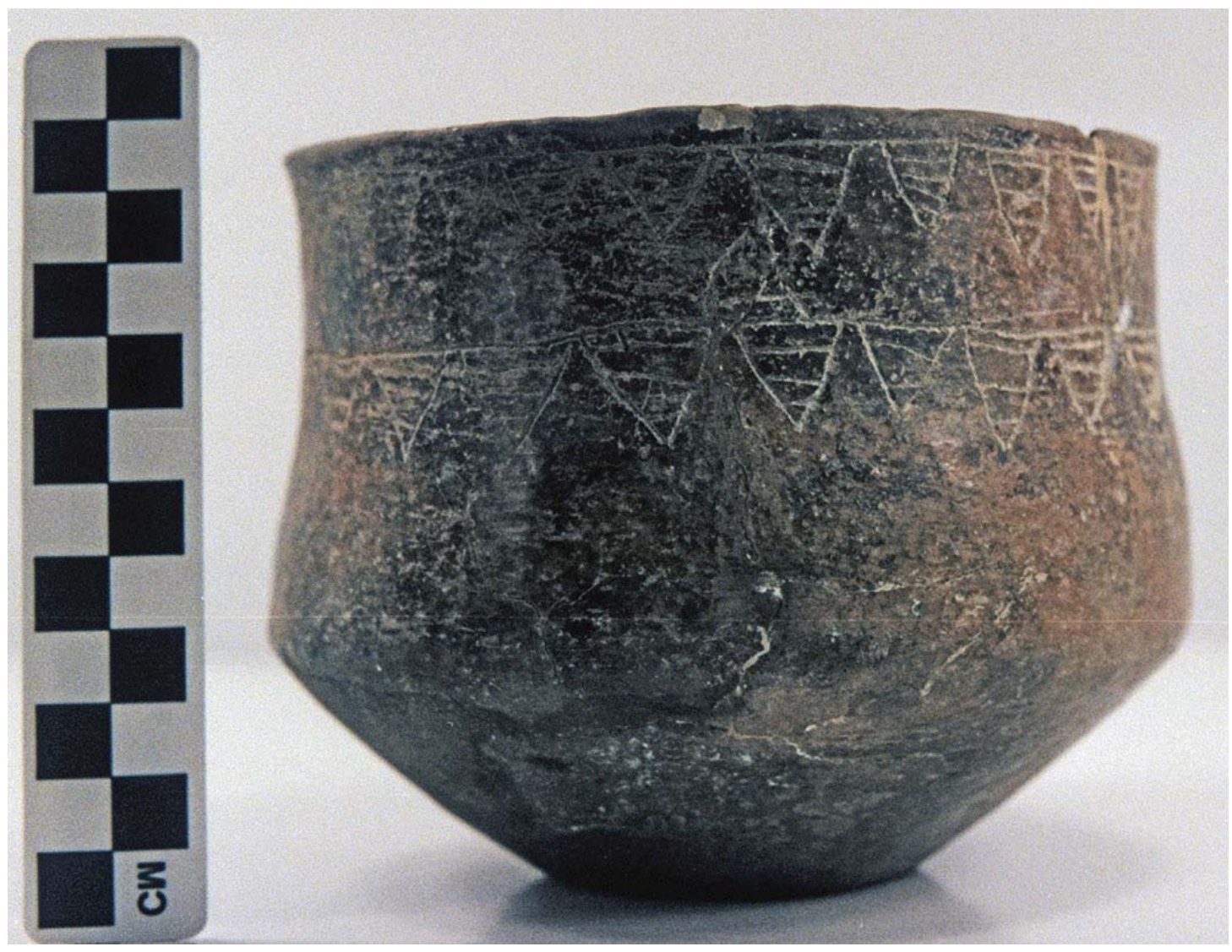

Figure 2. Poynor Engraved, var. $O$ carinated bowl. Catalog \#A317057, NMNH.

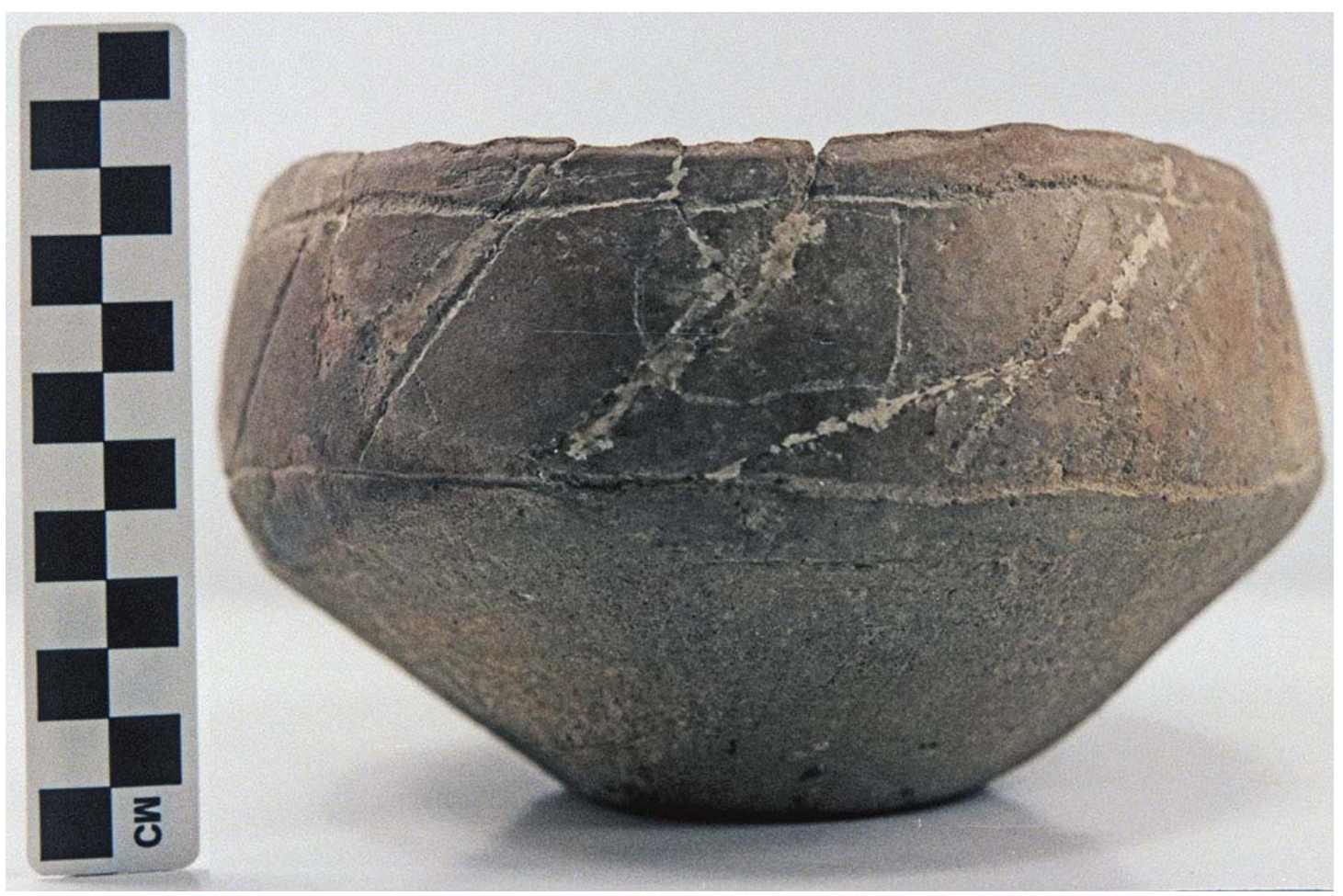

Figure 3. Poynor Engraved, var. unspecified carinated bowl. Catalog \#A317058, NMNH. 


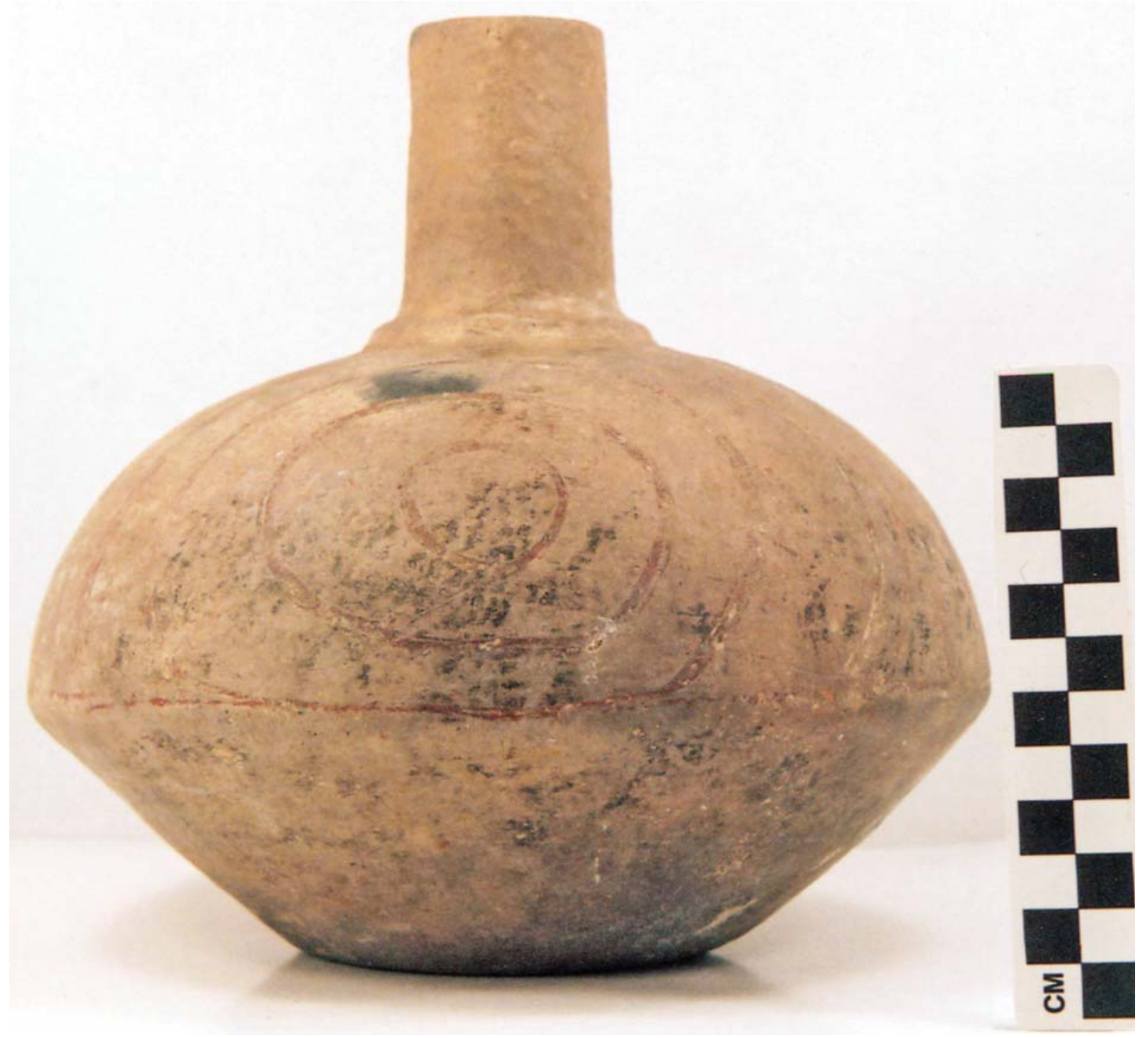

Figure 4. Poynor Engraved bottle. Catalog \#317055, NMNH.

Jelks 1962:83), and it is also decorated with a series of single vertical engraved lines from the top to the bottom of the vessel body (Figure 8).

Five of the fine ware vessels from the site are carinated bowls with engraved motifs. Four are Poynor Engraved vessels from Burials 2 and 6, and one is a Patton Engraved globular bowl from Burial 2. The Poynor Engraved carinated bowls are var. Freeman (Figure 10), var. Blackburn (Figure 11), var. Cook (Figure 12), and var. Hood (Figure 13) vessels (see Perttula 2011:Figure 6-64). The Patton Engraved carinated bowl is a var. Allen vessel with three horizontal engraved lines on the rim with downward-pointing excised pendant triangles (Figure 14, see Perttula 2011:Figure 6-66a).

Two of the vessels from this Cherokee County site are utility ware jars. The first is a Maydelle Incised vessel with four lip tabs and a series of incised triangles on the rim filled with tool punctations (Figure 15). 


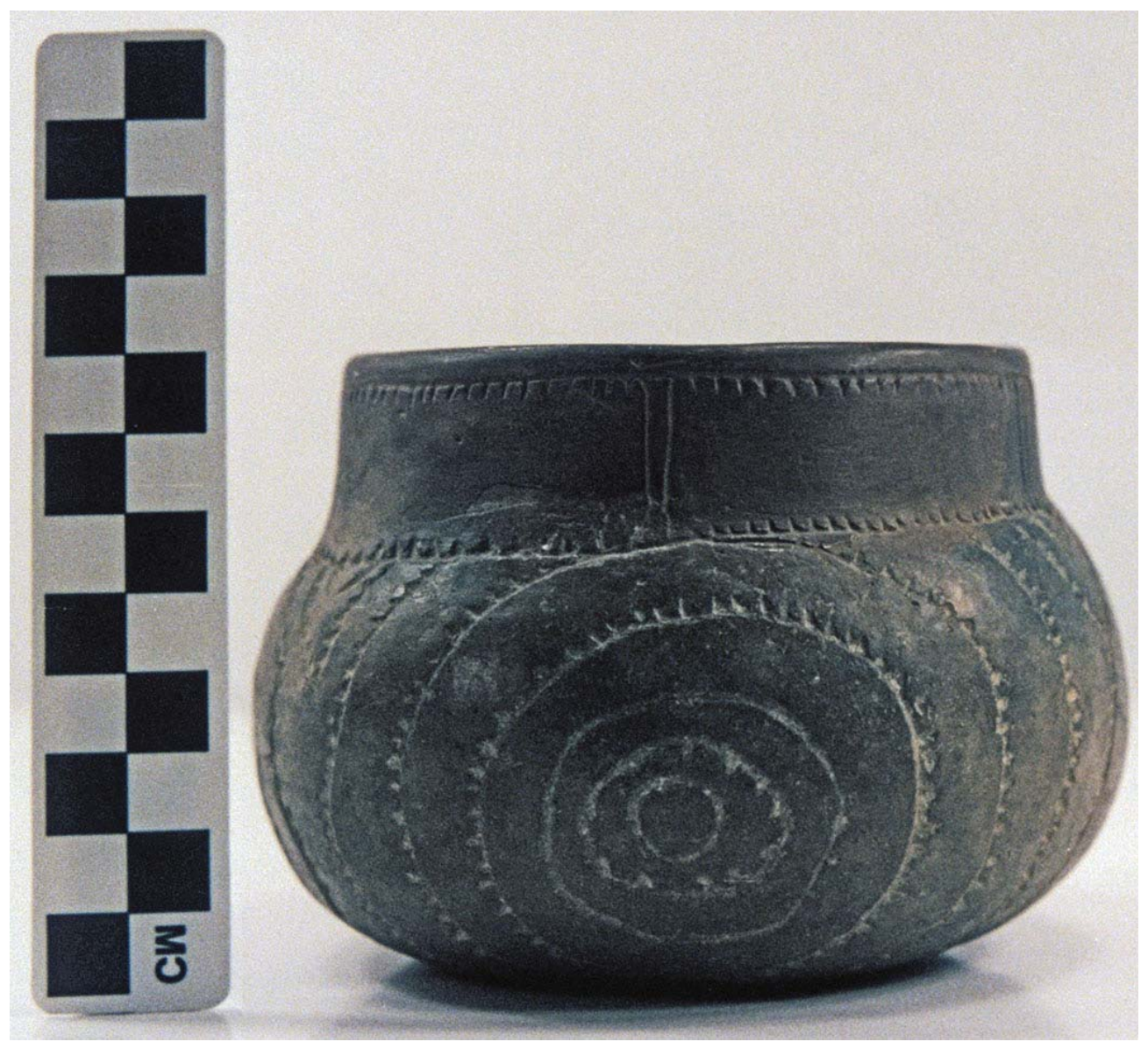

Figure 5. Patton Engraved, var. Freeman carinated bowl. Catalog \#514286, NMNH.

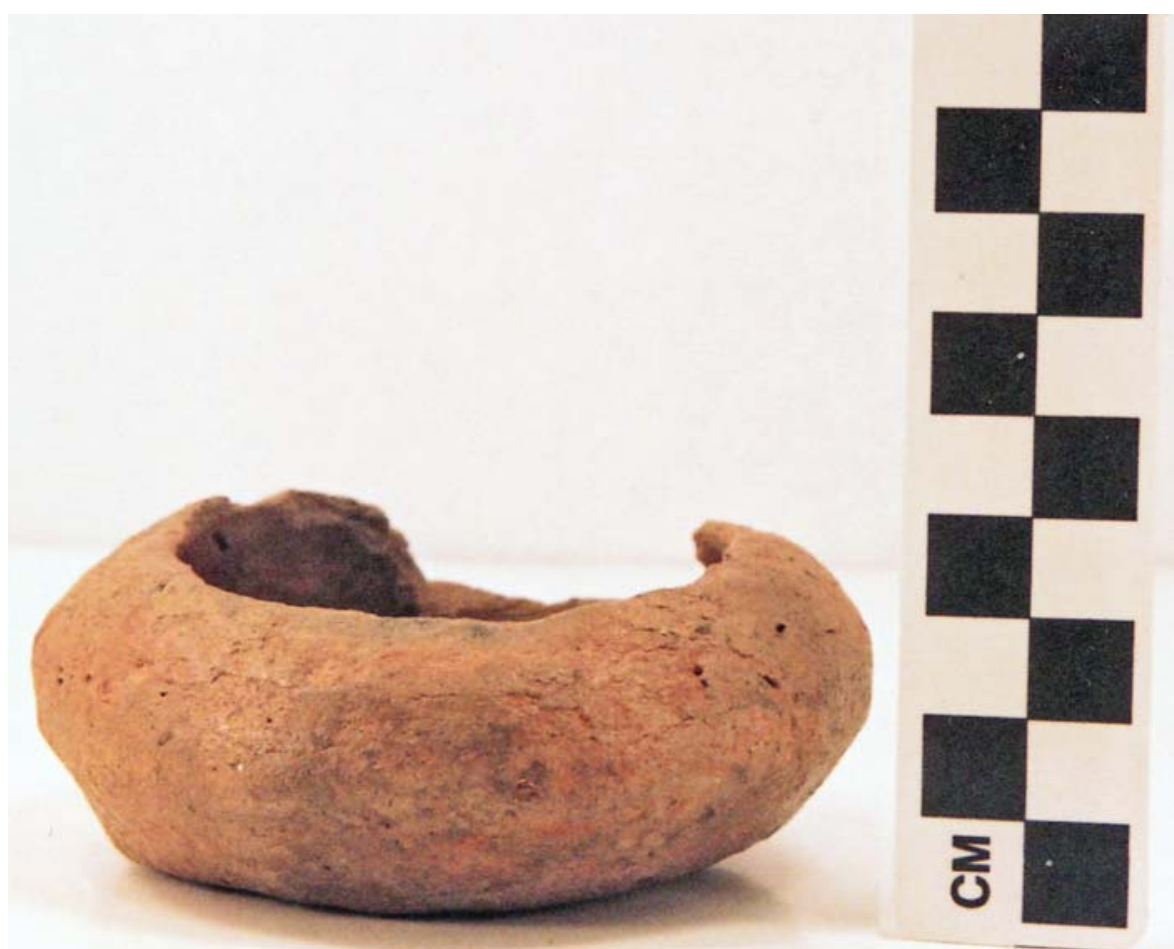

Figure 6. Plain bowl from 392/Ch-1, Cherokee County, Texas. Catalog \#A514261, NMNH. 


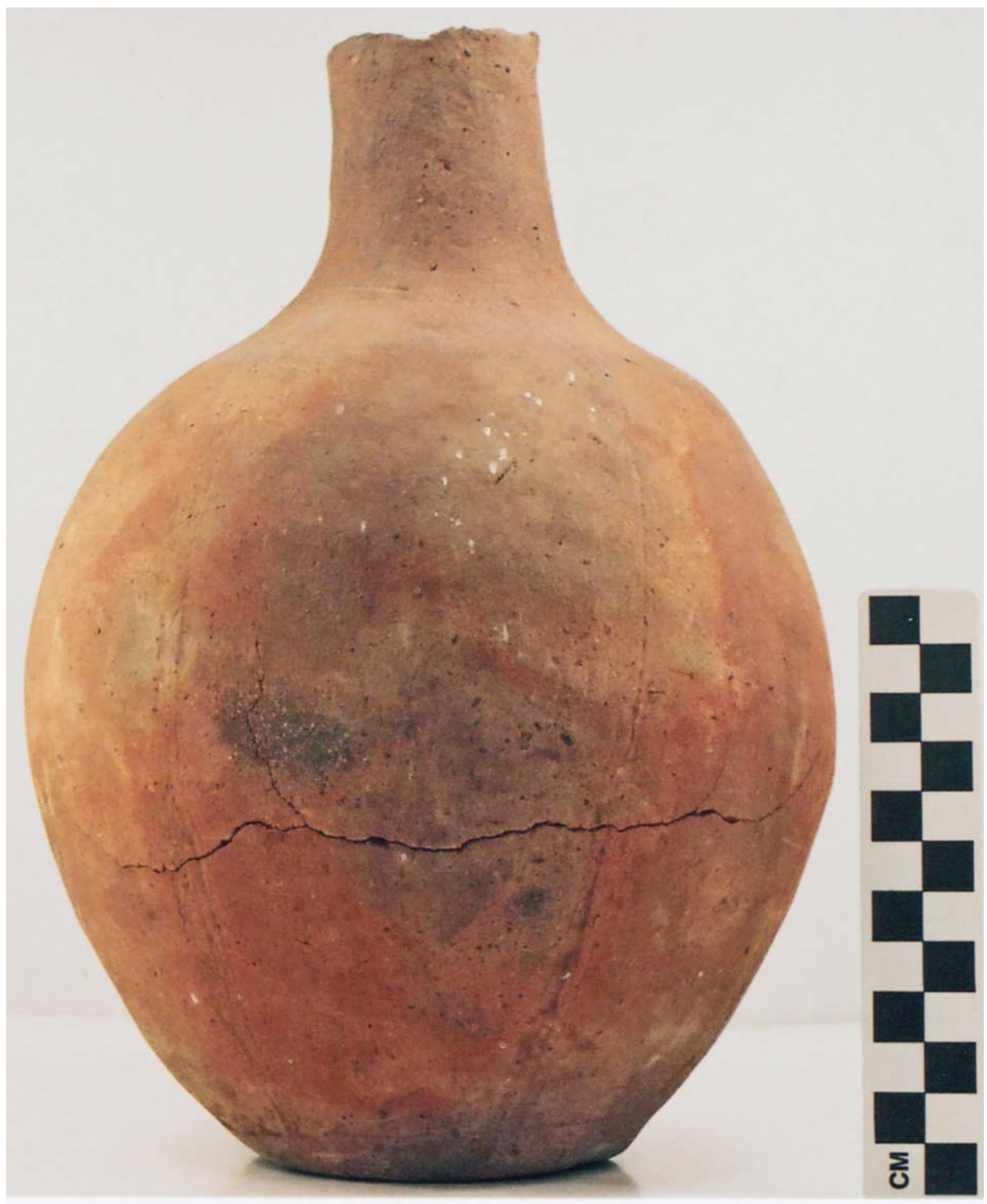

Figure 7. Poynor Engraved bottle from Burial 6. Catalog \#A514275, NMNH. 


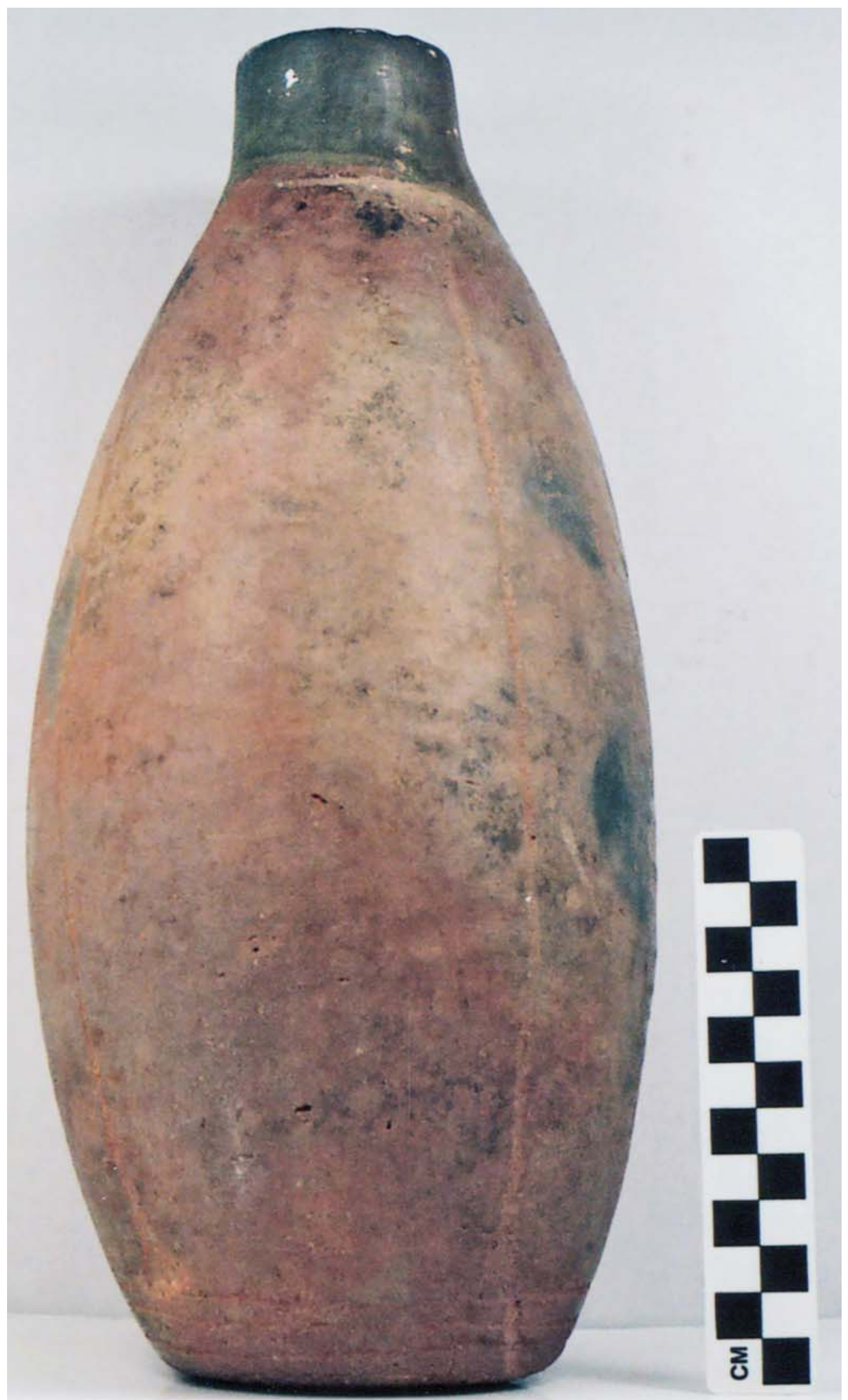

Figure 8. Hume Engraved bottle. Catalog \#A514260, NMNH. 


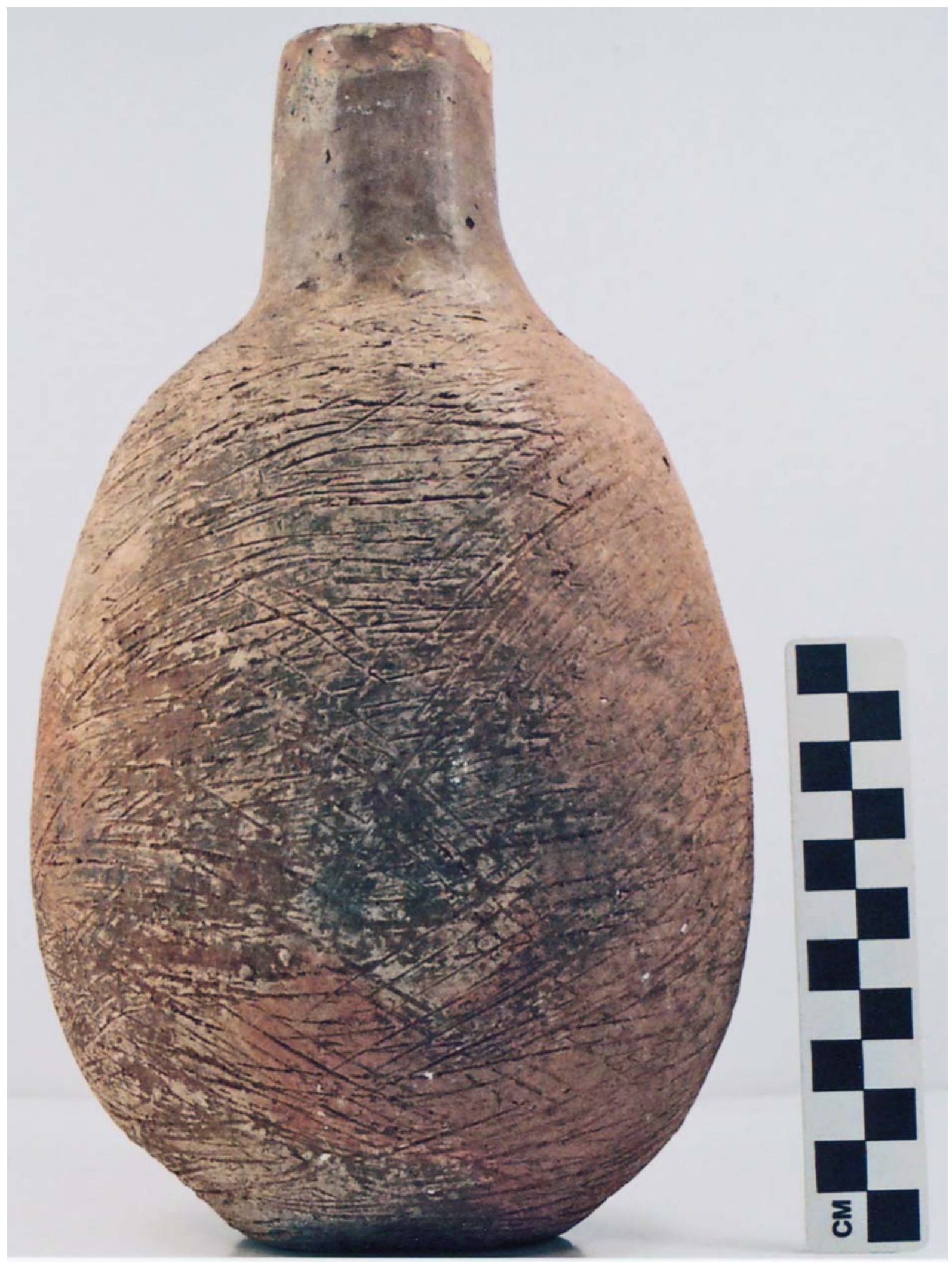

Figure 9. Poynor Brushed bottle from Burial 2. Catalog \#A514271. 


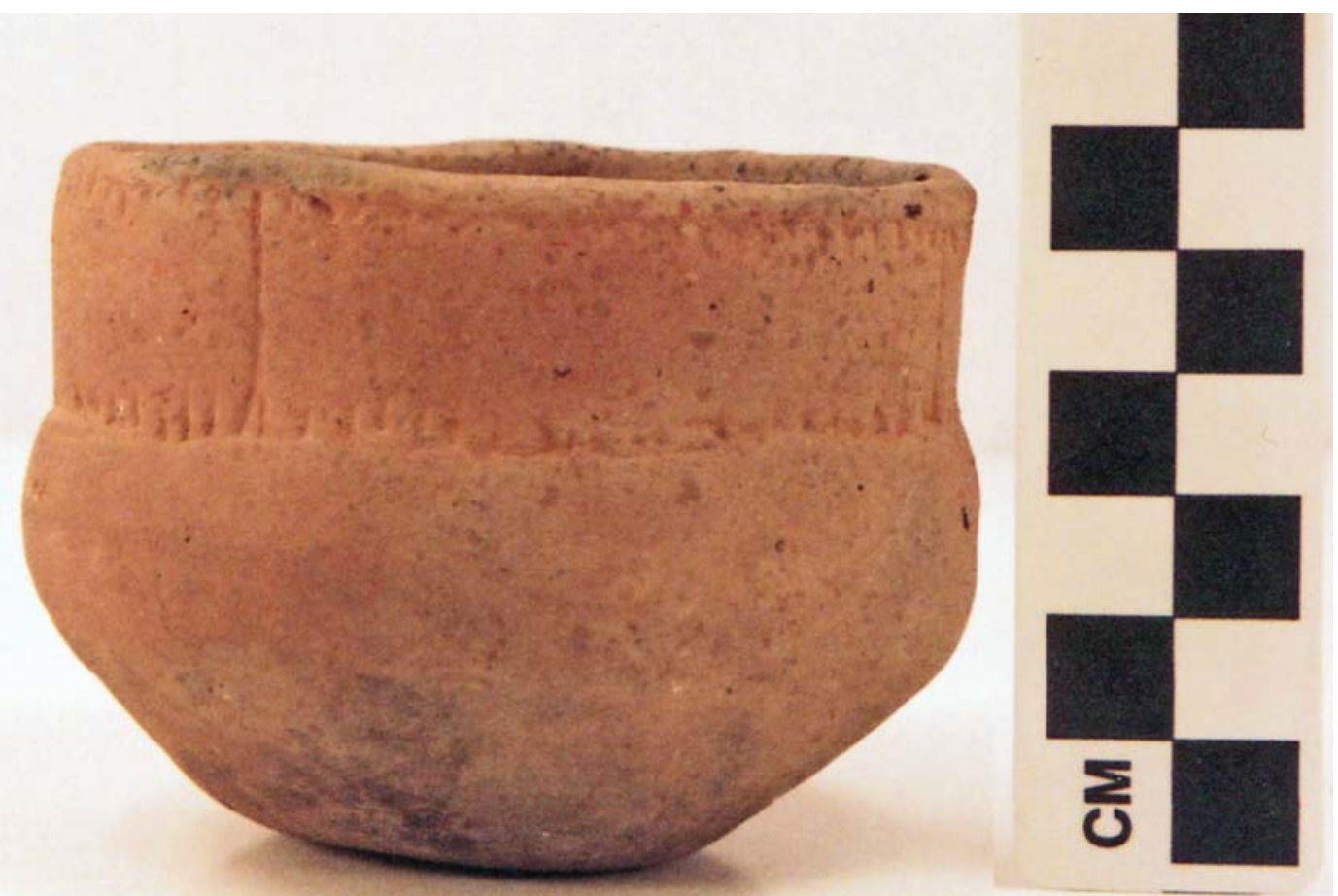

Figure 10. Poynor Engraved, var. Freeman carinated bowl from Burial 2. Catalog \#A514265, NMNH.

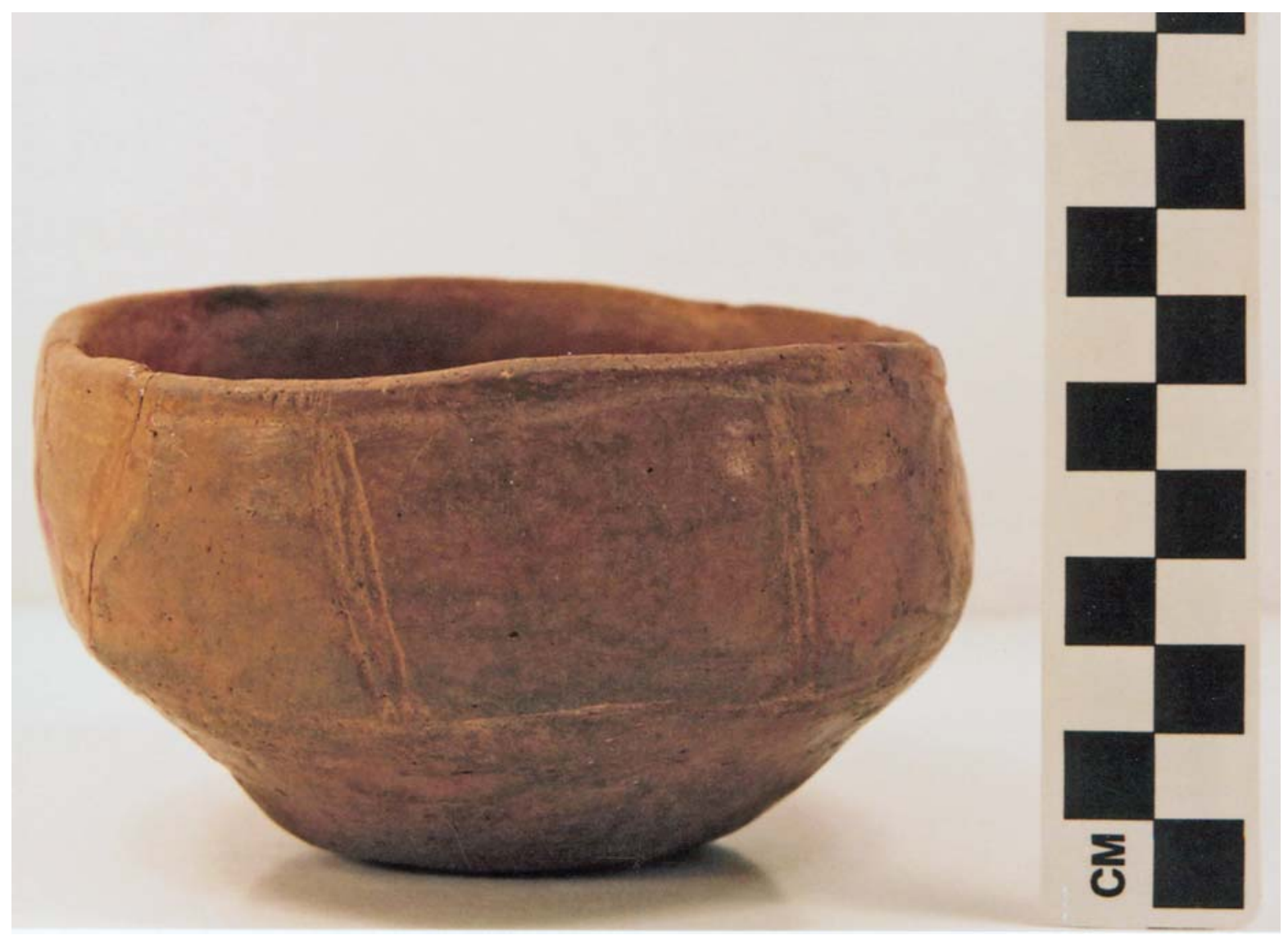

Figure 11. Poynor Engraved, var. Blackburn carinated bowl from Burial 2. Catalog \#A514266, NMNH. 


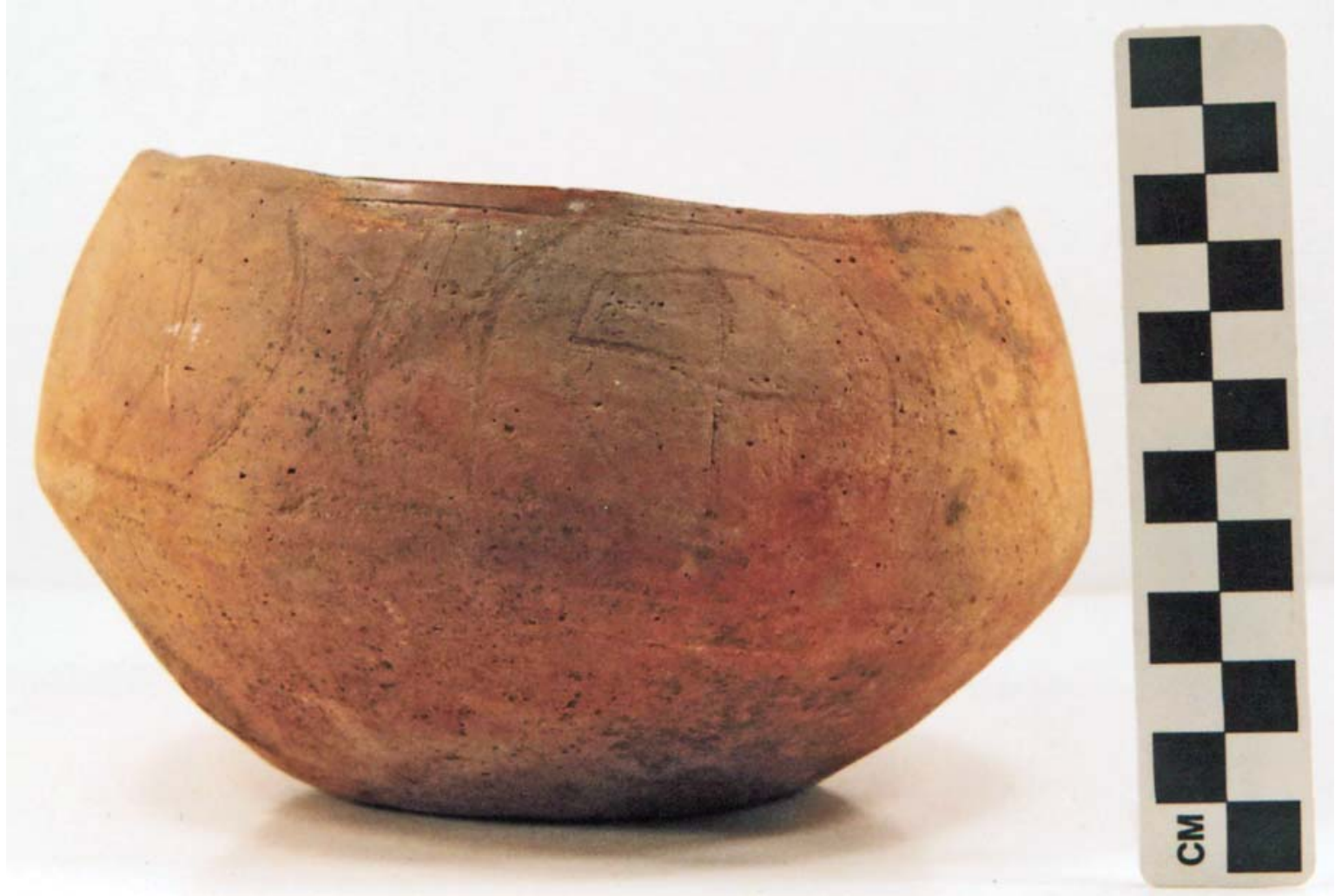

Figure 12. Poynor Engraved, var. Cook carinated bowl from Burial 2. Catalog \#A514267.

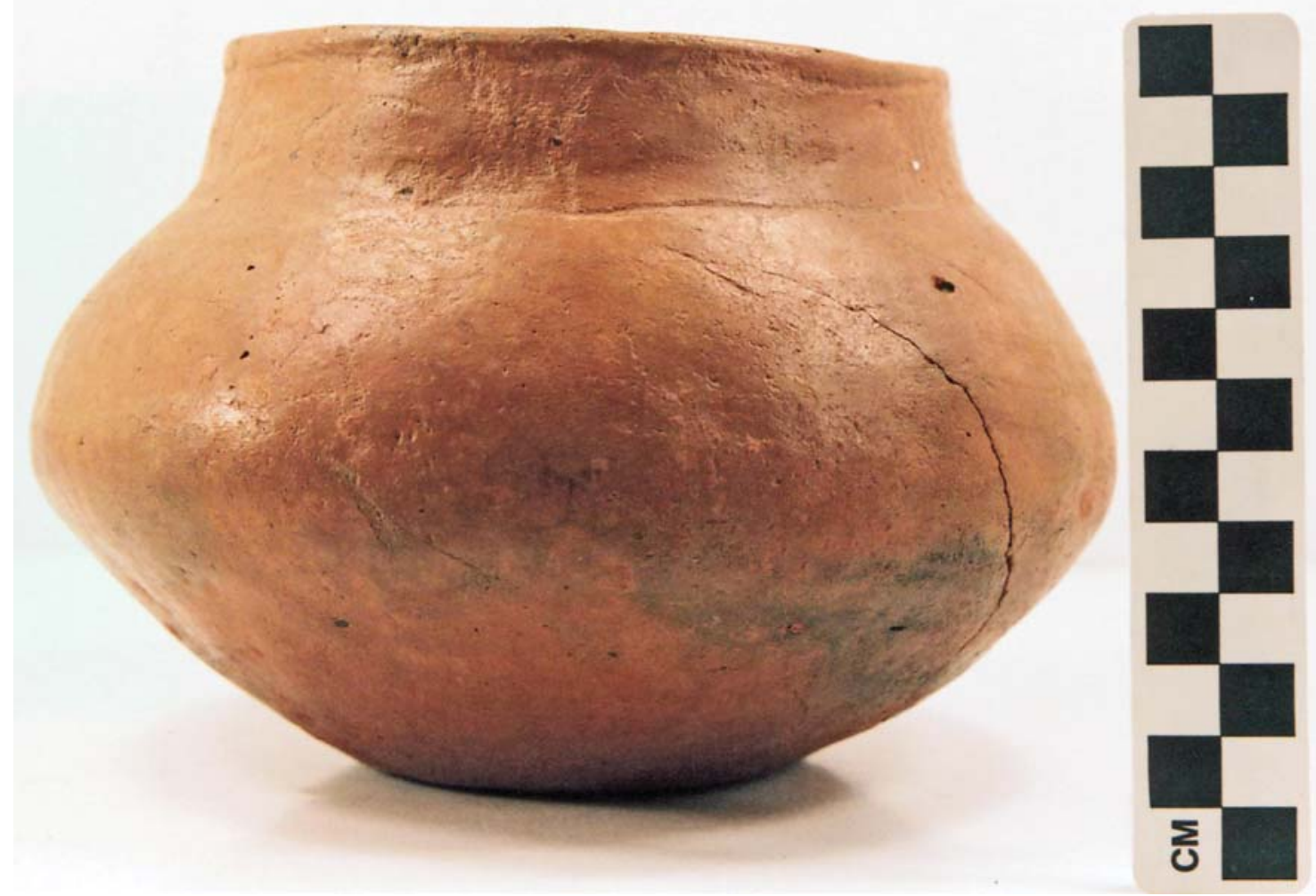

Figure 14. Patton Engraved, var. Allen carinated bowl from Burial 2. Catalog \#A514268, NMNH. 


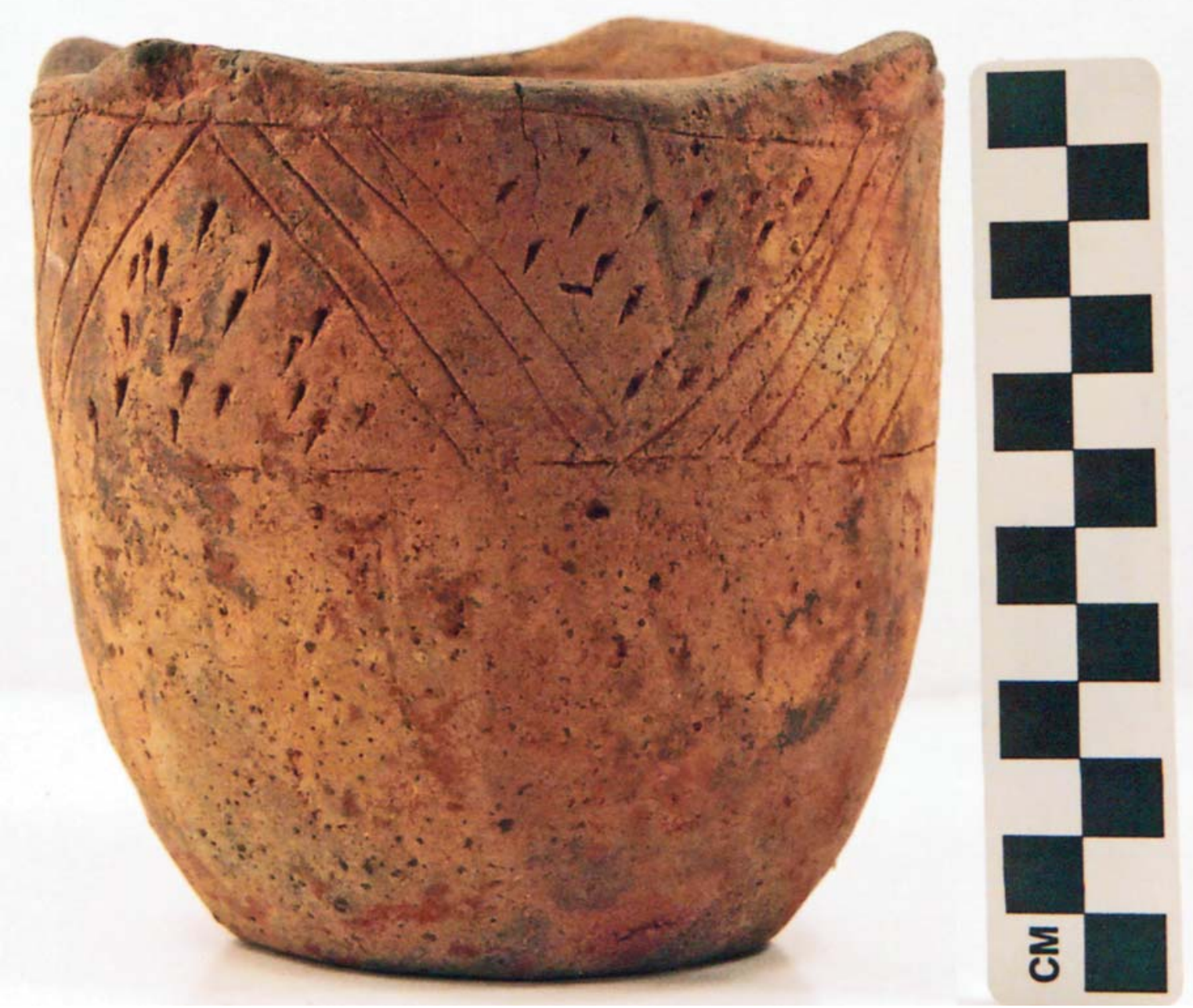

Figure 15. Maydelle Incised jar from Burial 2. Catalog \#A514270, NMNH.

The second utility ware jar has opposed lip lugs. It is decorated on the rim with two horizontal rows of large tool punctations either beneath the lip or at the rim-body juncture, with two horizontal grooved lines between the punctations (Figure 16). The vessel body has vertical brushing marks that extend nearly to the vessel base. The grooved decorative elements suggest this vessel is stylistically related to Lindsey Grooved utility wares, a distinctive historic Caddo Allen phase type in the upper Neches River basin (see Marceaux 2011).

The one ceramic pipe in the Cherokee County collection excavated by Harris from 392/Ch-1 is an elbow pipe with a ring pedestal base (Figure 17a-b). The pipe has a deep bowl and a lengthy stem. Jackson (1933:Plate 17:47) labels these pipes as thong hole pipes with holes at the base of the body. This Cherokee County pipe has three rows of small circular punctations on the pipe bowl, at the top and bottom of the pipe stem, and on the ring pedestal base.

\section{Henderson County}

The four Henderson County vessels in the R. K. Harris collection at the NMNH are labeled as coming from $392 / \mathrm{H} 1$ and $\mathrm{H} 2$. These are suspected to refer to two different burials from the same site, although it is possible the labels refer to two different Henderson County sites in the upper Neches River basin. 


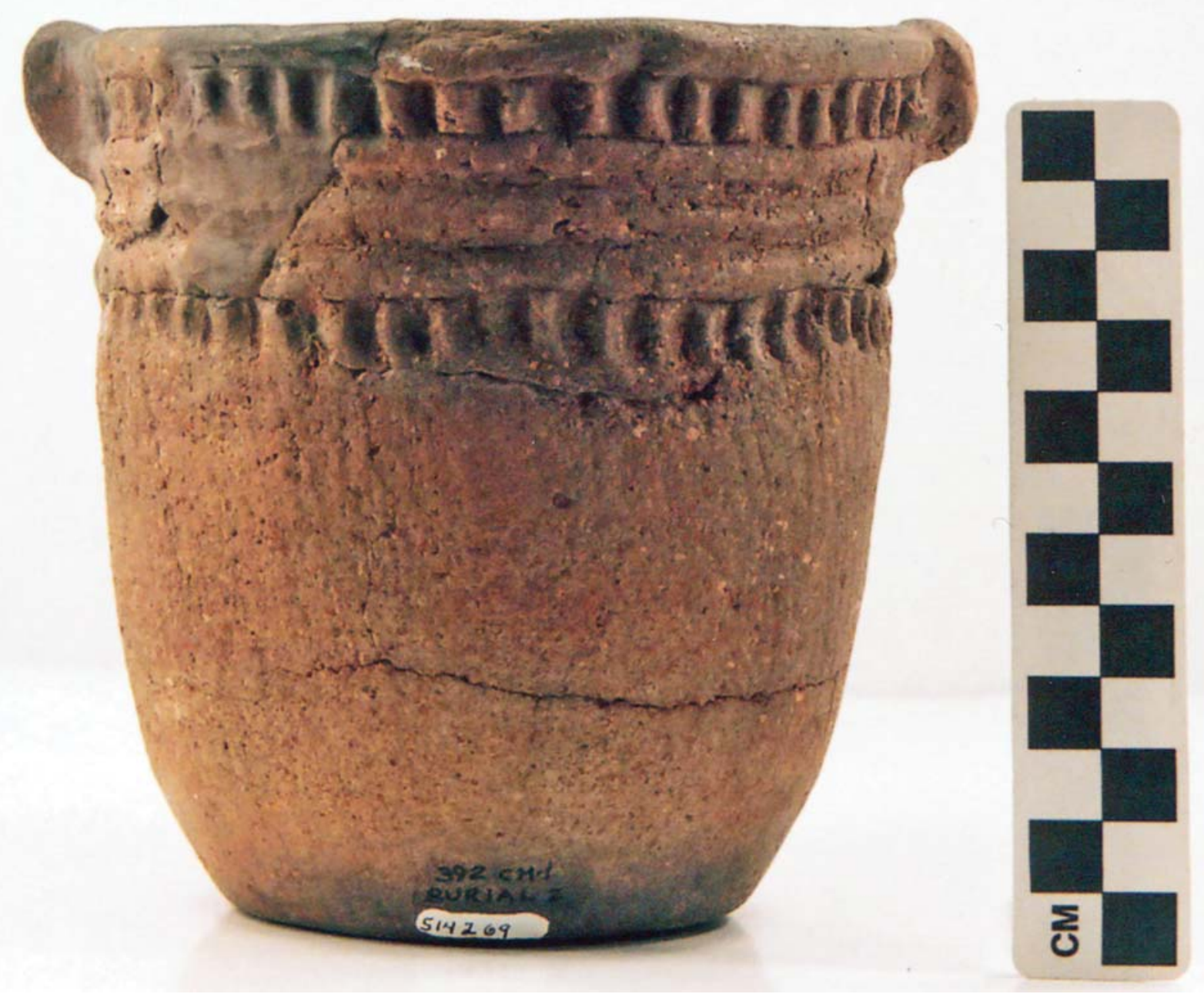

Figure 16. Punctated-grooved-brushed jar from Burial 2. Catalog \#A514269, NMNH.

The two vessels from 392/H1 include a Poynor Engraved, var. Cook carinated bowl (Figure 18) and a Hume Engraved, var. unspecified bottle (Figure 19). The Hume Engraved bottle has a very elongated body and a short neck with an everted rim. The body of the bottle is decorated with a series of narrow vertical zones filled with excised lines, and some zones have horizontal hatched pendant triangles. Another decorative element on the vessel body consists of curvilinear engraved lines with a series of hatched pendant triangles.

There are two ancestral Caddo vessels from 392/H2 in Henderson County, Texas. The first is a plain bottle with an elongated body and a spool neck (Figure 20). The second is a Hume Engraved, var. unspecified bottle with a continuous series of closely-spaced vertical engraved lines on the vessel body (Figure 21).

\section{Summary and Conclusions}

R. King Harris was an active amateur archaeologist that investigated Caddo sites in Arkansas, Louisiana, Oklahoma, and East Texas between 1924-1980. In 1980, his collections and records were purchased by the National Museum of Natural History, Smithsonian Institution. A number of the sites that Harris investigated and obtained collections from have not been reported or documented, and this includes the 19 ancestral Caddo ceramic vessels and one ceramic elbow pipe discussed herein from sites in Anderson, Cherokee, and Henderson counties in the upper Neches River basin. 

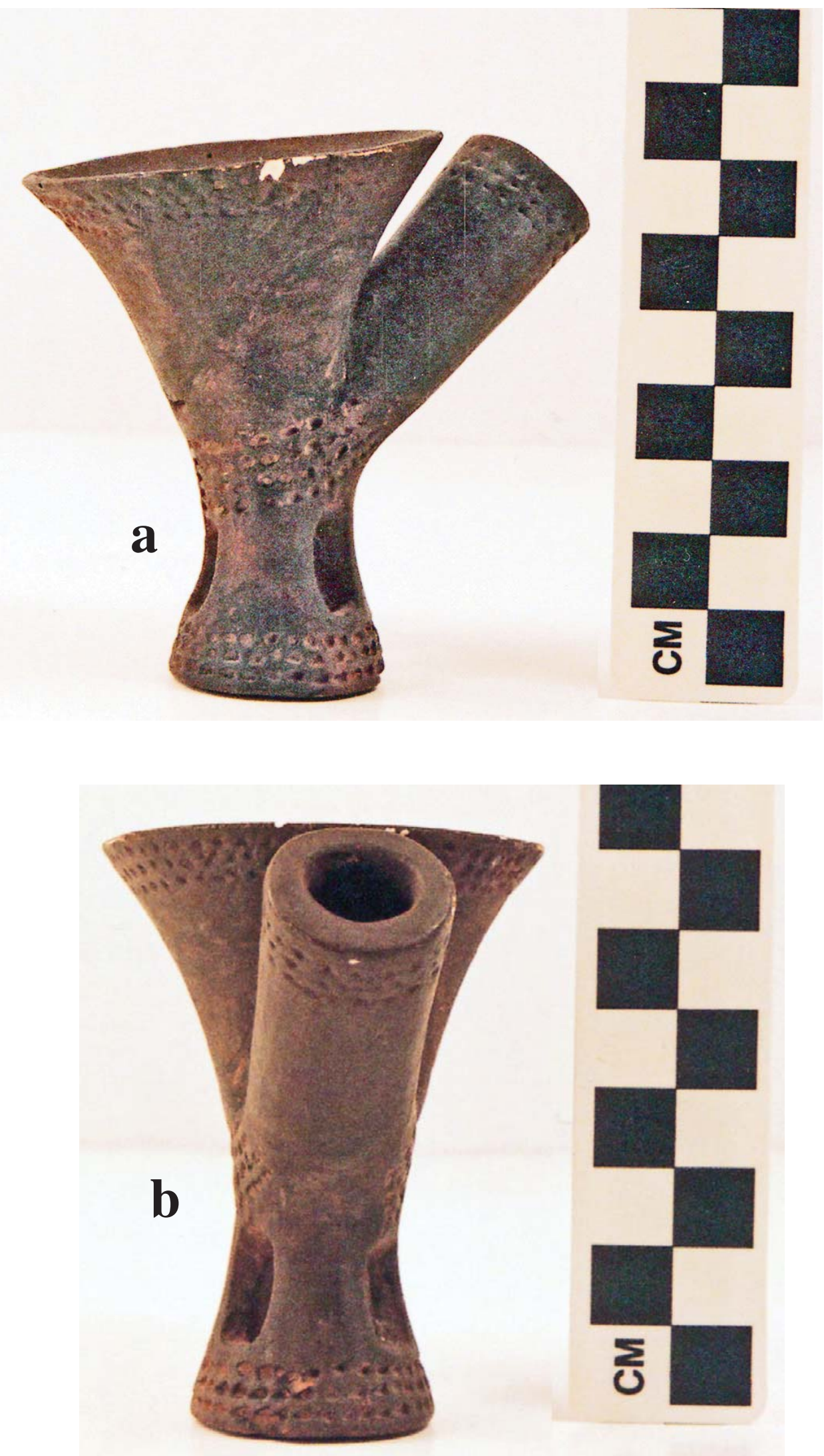

Figure 17. Ring pedestal base elbow pipe from 392/Ch-1. Catalog \#A514264, NMNH. 

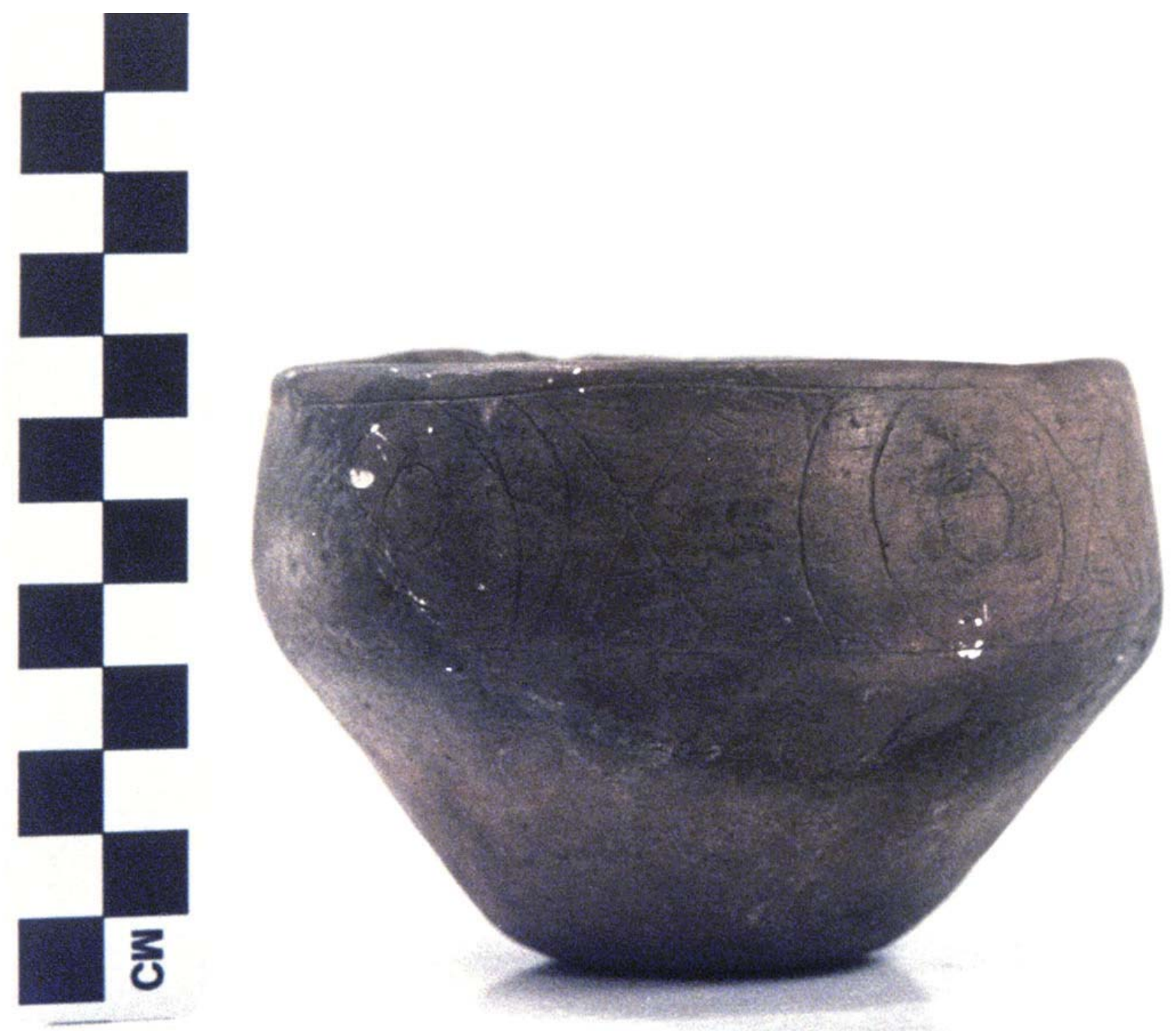

Figure 18. Poynor Engraved, var. Cook carinated bowl from H1. Catalog \#A514237, NMNH.

The Caddo ceramic vessels and ring pedestal base elbow pipe in the NMNH collections are from several burials excavated by Harris at different sites in the three counties. The decorative elements and motifs on the vessels, as well as the distinctive form of the carinated bowls and elongated Hume Engraved and Hume Plain bottles, indicate that they are from post-A.D. 1400 Late Caddo period, Frankston phase contexts as well as likely late $17^{\text {th }}$ century Allen phase contexts. The 19 vessels include a plain bottle (Hume Plain) and a plain bowl, two utility ware jars (Maydelle Incised and a punctated-groovedbrushed vessel), a Poynor Brushed bottle, and 14 fine ware carinated bowls and bottles. The bottles ( $\mathrm{n}=5$, 35.7 percent) are identified as Poynor Engraved $(\mathrm{n}=2)$ and Hume Engraved, var. unspecified $(\mathrm{n}=3)$. The other fine wares are Poynor Engraved $(n=7)$ and Patton Engraved $(n=2)$ carinated bowls. The Poynor Engraved carinated vessels in the Harris assemblage are var. Cook $(\mathrm{n}=2)$, var. Blackburn $(\mathrm{n}=1)$, var. Freeman $(\mathrm{n}=1)$, var. Hood $(\mathrm{n}=1)$, var. $O(\mathrm{n}=1)$, and var. unspecified $(\mathrm{n}=2)$. These varieties, as well as the Hume Engraved bottles, primarily occur in Frankston phase contexts at Caddo sites dating between ca. A.D. 1480-1680 (Perttula 2011:Table 6-37). The two Patton Engraved carinated bowls are var. Freeman and var. Allen. 


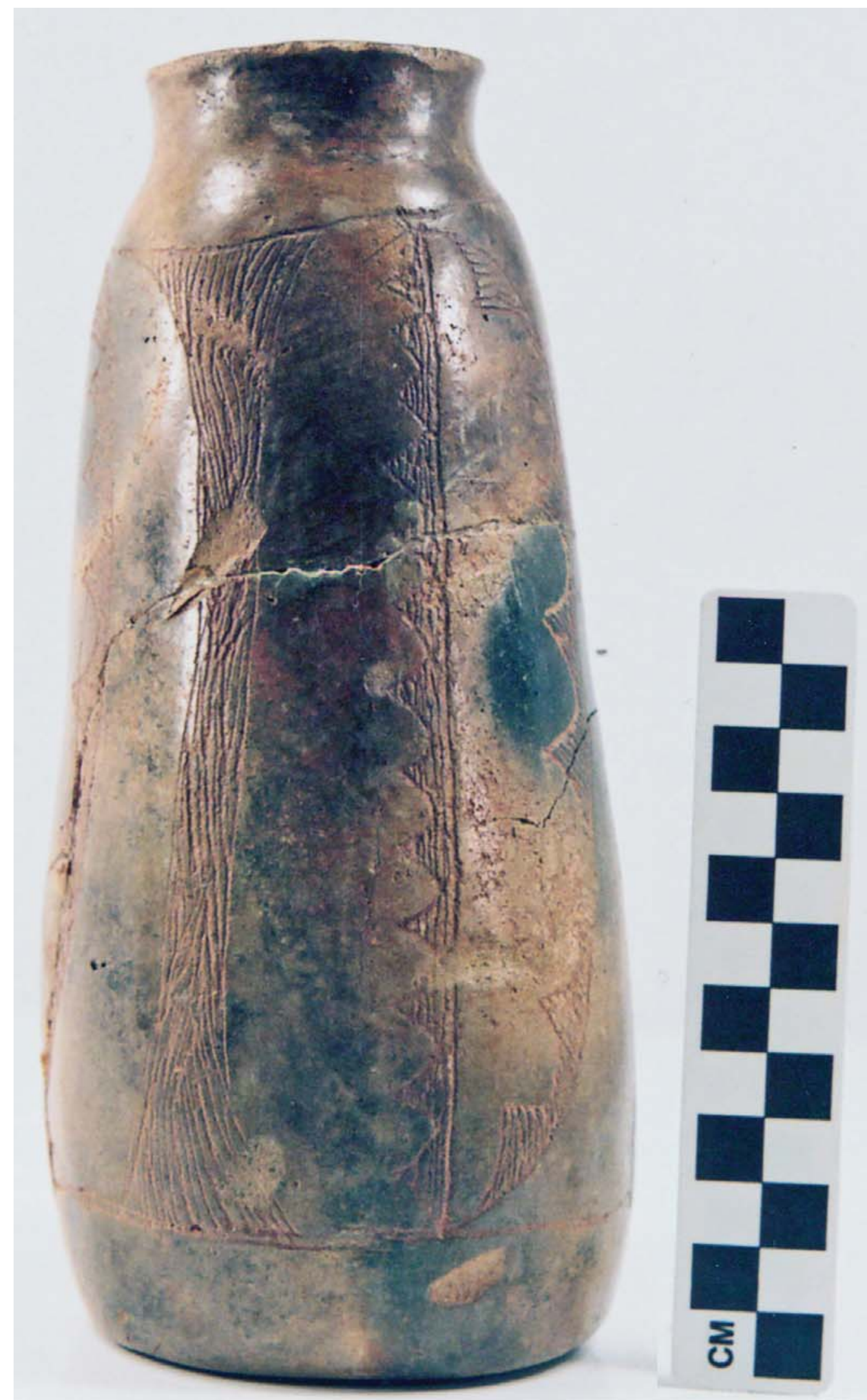

Figure 19. Hume Engraved, var. unspecified bottle from H1. Catalog \#A514236, NMNH. 


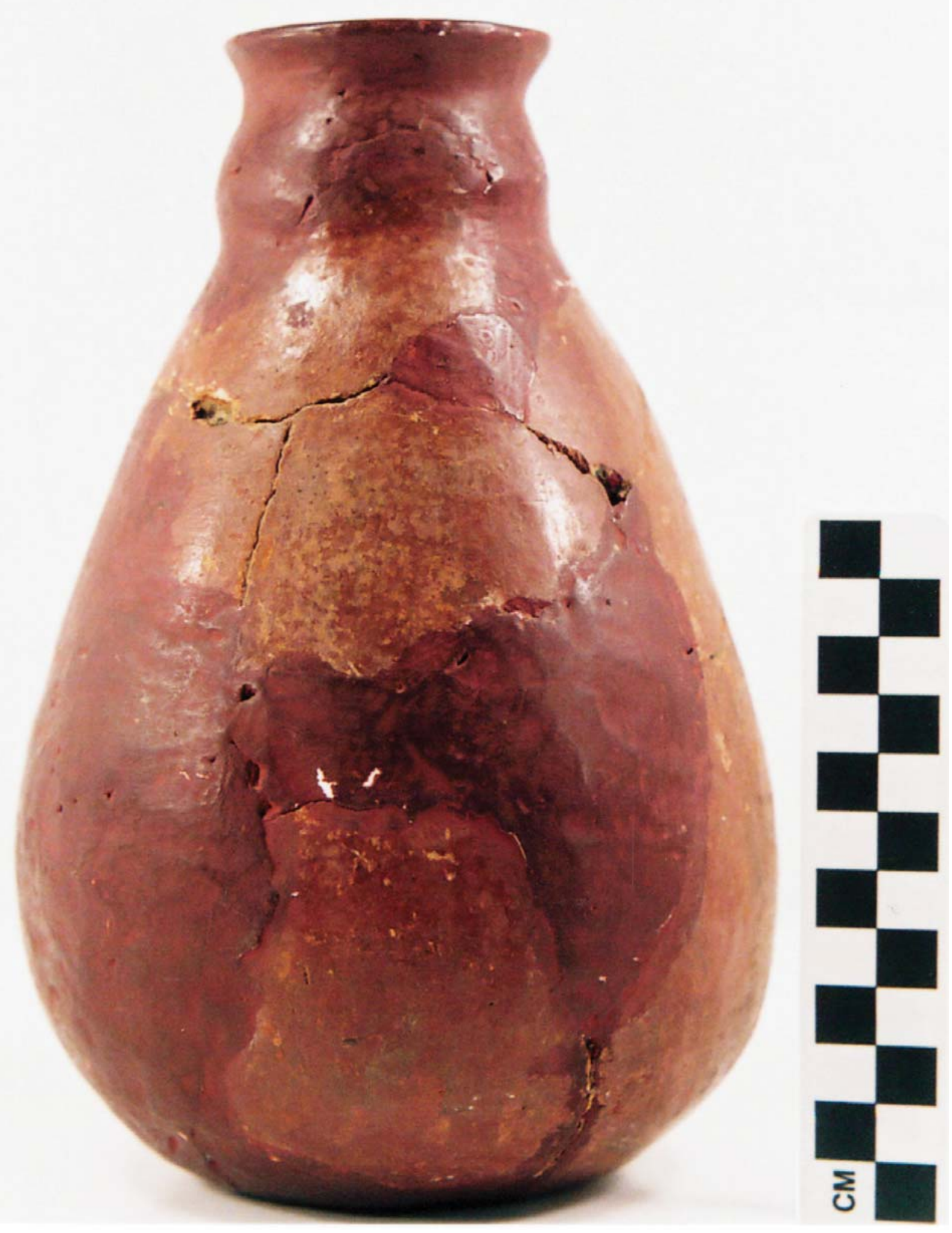

Figure 20. Hume Plain bottle from H2. Catalog \#A514241, NMNH. 


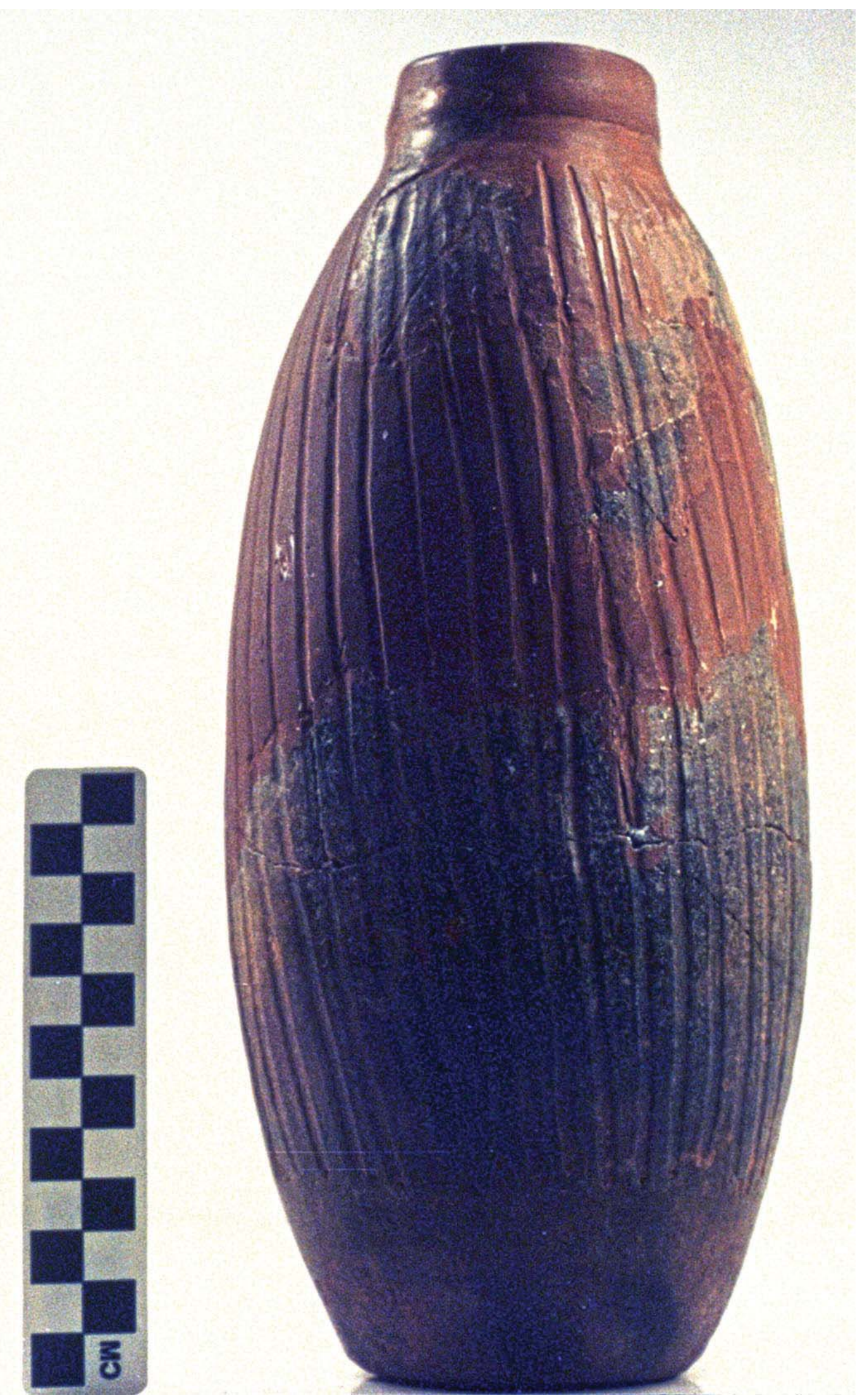

Figure 21. Hume Engraved, var. unspecified bottle from H2. Catalog \#A514242 


\section{Acknowledgments}

Bo Nelson took the photographs of the ceramic vessels and pipe in the NMNH used in this article, and Sandy Hannum prepared Figure 1.

\section{References Cited}

Jackson, A. T.

1933 Indian Pipes of East Texas. Bulletin of the Texas Archeological and Paleontological Society 5:69-86.

Marceaux, P. S.

2011 The Archaeology and Ethnohistory of the Hasinai Caddo: Material Culture and the Course of European Contact. Ph.D. dissertation, Department of Anthropology, The University of Texas at Austin.

Pearce, J. E.

1920 Explorations near Frankston, Texas. MS on file, Texas Archeological Research Laboratory, The University of Texas at Austin.

1932 The Present Status of Texas Archeology. Bulletin of the Texas Archeological and Paleontological Society 4:44-54.

Perttula, T. K.

2011 The Ceramic Artifacts from the Lang Pasture Site (41AN38) and the Place of the Site within an Upper Neches River Basin Caddo Ceramic Tradition. In Archeological Investigations at the Lang Pasture Site (41AN38) in the Upper Neches River Basin of East Texas, assembled and edited by T. K. Perttula, D. B. Kelley, and R. A. Ricklis, pp. 145-320. Archeological Studies Program Report No. 129. Texas Department of Transportation, Environmental Affairs Division, Austin.

Suhm, D. A. and E. B. Jelks (editors)

1962 Handbook of Texas Archeology: Type Descriptions. Special Publication No. 1, Texas Archeological Society, and Bulletin No. 4, Texas Memorial Museum, Austin. Reprinted in 2009, Gustav's Library, Davenport, Iowa. 